\title{
ABNORMAL RETURN SAHAM DAN TRADING VOLUME ACTIVITY SEBELUMDAN SESUDAH KEBIJAKAN COUNTERCYCLICAL PADA PERUSAHAAN KEUANGAN YANG TERDAFTAR DI BURSA EFEK INDONESIA
}

\author{
Marcellino Willyan Lasano ${ }^{1}$, Iqbal M Aris Ali ${ }^{2}$, Muhamad Yamin Noch $^{3}$, Victor Pattiasina ${ }^{4}$ \\ Eduard Yohanis Tamaela ${ }^{5}$ \\ 1-2 Fakultas Ekonomi dan Bisnis, Universitas Khairun Ternate \\ ${ }^{3-4}$ Fakultas Ekonomi dan Bisnis, Universitas Yapis Papua \\ ${ }^{5}$ STIA Said Perintah Masohi \\ e-mail: victorpattiasina@ppsuniyap.co.id
}

\begin{abstract}
Abstrak
Tujuan Penelitian ini adalah untuk membedah korelasi antara Abnormal Return dan Aktivitas Volume Perdagangan sebelumnya, kemudian setelah fakta POJK nomor 11 tahun 2020 dan POJK nomor 14 tahun 2020. Strategi pengujian menggunakan Puposive Sampling. Uji eksplorasi mutlak adalah 51 organisasi di bidang moneter yang tercatat di BEI. Pengujian teori yang digunakan adalah Wilcoxon Signed Ranks Test dengan menggunakan SPSS. Hasil menunjukkan bahwa ada perbedaan yang signifikan penting dalam pengembalian yang tidak biasa sebelumnya, kemudian setelah fakta strategi kontra-siklus, sementara pertukaran tindakan volume tidak menunjukkan perbedaan yang signifikan.
\end{abstract}

Kata Kunci: Kebijakan Countercyclical, Pengembalian Tidak Normal dan Aktivitas Volume Perdagangan.

\section{PENDAHULUAN}

Bunga secara keseluruhan adalah situasi berbagai aset saat ini dengan keinginan untuk memperoleh keuntungan di kemudian hari. Usaha sebagian besar dipisahkan menjadi dua, khususnya minat pada sumber daya moneter dan minat pada sumber daya asli. Sumber daya moneter, khususnya autentikasi, penyimpanan, perlindungan, dll, sedangkan sumber daya asli adalah membuka pertambangan, membangun pabrik, dll. Namun, spekulasi juga dapat dilakukan di pasar modal, misalnya saham dan surat berharga. untuk menempatkan sumber daya ke pasar modal memerlukan informasi, pengalaman, dan dorongan bisnis yang memadai dalam menyelidiki efek mana yang harus dibeli dan mana yang akan dijual dan mana yang harus dipertahankan.(Hidayah, 2019).

Melihat kondisi perekonomian Indonesia yang sangat menegangkan telah menyebabkan terjadinya revisi serius di pasar modal Indonesia. Indeks Harga Saham Gabungan (IHSG) telah turun $22 \%$ menjelang awal tahun 2020. Pasar modal Indonesia adalah salah satu negara yang mengalami penurunan yang cukup luar biasa. Karena pandemi Covid-19, pergerakan dan pertukaran moneter menjadi terhambat. Otoritas Jasa Keuangan (OJK) terus mengupayakan pelaksanaan dan administrasi pertukaran yang produktif dan terorganisir untuk semua mitra. untuk kesesuaian fungsional atau pergerakan pasar.

Mengingat semakin merebaknya penyebaran COVID-19 yang implikasinya berdampak pada keterjangkauan dan limit pemegang rekening dalam memenuhi komitmen angsuran kredit atau pembiayaan dan dapat mengganggu pelaksanaan perbankan dan keamanan kerangka moneter sehingga dapat mempengaruhi perkembangan moneter, OJK menetapkan Peraturan Otoritas Jasa Keuangan tentang Stimulus Perekonomian Nasional. Sebagai Kebijakan Countercyclical Akibat Penyebaran Corona Virus Disease 2019. Peraturan Otoritas Jasa Keuangan ini mulai berlaku pada tanggal ditetapkan, yaitu pada tanggal 13 Maret 2020 dan 14 April 2020.

Berdasarkan gambaran di atas, dengan adanya Fenomena yang terjadi, para peneliti tertarik pada penelitian dengan judul "Aktivitas Pengembalian Saham dan Aktivitas Volume Perdagangan Sebelum dan Sesudah Kebijakan Countercyclical pada Perusahaan Keuangan yang Terdaftar di Bursa Efek Indonesia (Event Study)" 


\section{TINJAUAN PUSTAKA \\ Signalling Theory}

Signaling Theory atau Sinyal Yang dikembangkan oleh (Ross, 1977), menyatakan bahwa pimpinan organisasi yang memiliki data lebih baik tentang organisasinya akan terdorong untuk menyampaikan data ini kepada pendukung keuangan potensial sehingga biaya persediaan organisasi meningkat. Hal positif dalam flagging hipotesis adalah bahwa organisasi yang memberikan data yang baik akan memisahkan mereka dari organisasi lain yang tidak memiliki berita menggembirakan (delightful news) dengan memberikan penerangan kepada pasar modal tentang kondisi organisasi tersebut, sebuah pertanda tentang eksekusi yang baik di masa depan. diberikan oleh organisasi yang presentasi moneternya di masa lalu tidak baik tidak dipercaya oleh pasar yang diungkapkan (Wolk, $\mathrm{H}$. I, 1997).

Standar penandaan ini menginstruksikan bahwa setiap aktivitas berisi data. Hal ini dikarenakan adanya data yang menyimpang. Data miring adalah kondisi dimana salah satu pihak memiliki data yang lebih banyak dari pihak lainnya. Misalnya, administrasi organisasi memiliki lebih banyak informasi daripada pendukung keuangan di pasar modal.

\section{Ffisiensi Pasar}

Dalam gagasan pasar yang efektif, perubahan biaya sekuritas saham di masa lalu tidak dapat digunakan untuk mengantisipasi perubahan biaya di masa depan. Perubahan harga persediaan di pasar produktif mengikuti desain jalan sewenang-wenang, di mana pengukur biaya persediaan tidak dapat dilakukan dengan melihat harga persediaan yang dapat diverifikasi, tetapi lebih bergantung pada semua data yang tersedia dan muncul di pengamatan. Data yang masuk ke pasar dan mengidentifikasi dengan keamanan saham akan membawa kemungkinan perubahan lain dalam biaya keseimbangan. Jika pasar merespon dengan cepat dan tepat terhadap data yang mendekati dan dengan cepat membentuk nilai keseimbangan lain, maka, pada saat itu, situasi ekonomi seperti ini disebut pasar produktif (Hartono, 2013).

\section{Event Study}

Studi kesempatan adalah ilmu yang mengkonsentrasikan respon yang tersedia terhadap suatu kejadian yang datanya didistribusikan sebagai suatu deklarasi (Indriastuti, 2018). Artikel-artikel yang dapat digunakan dalam kesempatan berkonsentrasi pada penelitian adalah data yang terdistribusi secara lengkap. Data tersebut mencakup semua peristiwa dalam skala besar, miniatur, bagian luar interior organisasi, masalah pemerintahan, hukum, periklanan, eksekutif, sejarah, dan berbagai ilmu yang diproklamirkan sebagai deklarasi (Lestari \& Nuzula, 2018).

Peristiwa yang dimaksud adalah peristiwa yang informasinya diumumkan sebagai pengumuman. Jika pengumuman tersebut mengandung informasi, maka diharapkan pasar akan bereaksi ketika pengumuman tersebut diterima oleh pasar. Reaksi pasar ini dapat diukur dengan menggunakan return berupa nilai perubahan harga atau dengan menggunakan abnormal return. Jika digunakan abnormal return maka dapat dikatakan bahwa suatu pengumuman yang mengandung kandungan informasi akan memberikan abnormal return kepada pasar.

\section{Peraturan OJK NOMOR 11/ POJK.03/2020}

Otoritas Jasa Keuangan (OJK) Republik Indonesia menetapkan POJK Nomor 11/POJK.03/2020 tentang Peningkatan Moneter Masyarakat sebagai strategi countercyclical karena penyebaran infeksi Covid 2019 di lembaga bantuan moneter bank. untuk memikirkan beberapa hal, khususnya:

1. Peningkatan penyebaran infeksi Covid 2019 (COVID-19) di seluruh dunia secara tidak langsung mempengaruhi pameran dan batas individu yang berutang dalam memenuhi komitmen angsuran kredit atau pembiayaan

2. pengaruh terhadap eksekusi dan limit peminjam akan meningkatkan bahaya kredit yang dapat mengganggu pelaksanaan keuangan dan kekuatan kerangka moneter sehingga dapat mempengaruhi perkembangan keuangan;

3. Untuk mendorong peningkatan kinerja perbankan, khususnya kerja intermediasi, menjaga keamanan kerangka moneter, dan mendukung perkembangan keuangan, perlu diambil strategi dorongan moneter sebagai efek countercyclical dari penyebaran infeksi Covid 2019 (COVID- 19);

Penyebaran penyakit Covid-19 (COVID-19) di seluruh dunia berdampak pada meningkatnya risiko kredit bank karena berkurangnya eksekusi peminjam dan batas pemenuhan komitmen angsuran 
kredit atau pembiayaan. Risiko kredit yang meluas dapat mengganggu kinerja keuangan dan kekuatan kerangka moneter yang dapat mempengaruhi perkembangan moneter, sehingga diperlukan pendekatan countercyclical.

\section{Peraturan OJK NOMOR 14/POJK.05/2020}

Otoritas Jasa Keuangan (OJK) Republik Indonesia menetapkan POJK nomor 14/POJK.05/2020 melihat perbaikan moneter publik sebagai strategi countercyclical dampak penyebaran penyakit Covid 2019 berkumpulnya administrasi moneter non-bank. untuk memikirkan beberapa hal, lebih spesifik:

1. Bahwa perkembangan penyebaran penyakit Covid-19 2019 (COVID-19) di seluruh dunia secara tidak langsung mempengaruhi pameran dan batas fungsional diskusi administrasi moneter pembeli dan non-bank yang mungkin dapat mengganggu penyelenggaraan pertemuan administrasi moneter non-bank dan keamanan kerangka moneter untuk mempengaruhi perkembangan keuangan

2. Meskipun untuk mendorong peningkatan penyelenggaraan rapat administrasi moneter non-bank, menjaga ketergantungan kerangka moneter, dan mendukung perkembangan keuangan, penting untuk mengambil pendekatan countercyclical dari dampak penyebaran COVID-19 dengan tetap fokus pada standar kewajaran;

3. Sedangkan mengingat hal sebagaimana dimaksud pada huruf a dan huruf $b$, penting untuk menetapkan Peraturan Otoritas Jasa Keuangan tentang Kebijakan Countercyclical Karena Penyebaran Corona Virus Disease 2019 dalam rangka perkumpulan Jasa Keuangan Bukan Bank;

Penyebaran COVID-19 di seluruh dunia secara tidak langsung memengaruhi presentasi dan batas fungsional pembeli dan LKNB. Efek pada pameran dan limit fungsi nasabah dan LKNB mungkin dapat mengganggu kinerja LKNB dan kemantapan kerangka moneter sehingga dapat mempengaruhi perkembangan keuangan. Dengan demikian, pengaturan countercyclical tertentu diharapkan dapat mengikuti pelaksanaan LKNB, menjaga keamanan kerangka moneter, dan mendukung perkembangan keuangan. Forum Jasa Keuangan Non Bank yang selanjutnya disebut LJKNB adalah wadah yang berisi tentang kegiatan-kegiatan di bidang proteksi, pencadangan manfaat, pembahasan pembiayaan, dan pembahasan administrasi moneter lainnya.

\section{Indek Saham}

Daftar saham adalah ukuran faktual yang mencerminkan perkembangan nilai umum dari kumpulan saham yang dipilih dengan model dan sistem tertentu dan dinilai secara konsisten. Tujuan keuntungan catatan stok meliputi:

1. Memperkirakan perasaan pasar

2. Digunakan sebagai item spekulasi yang tidak terlibat, misalnya Reksa Dana Indeks dan ETF Indeks hanya sebagai item subordinat

3. Tolok ukur untuk portofolio dinamis

4. Perantara dalam memperkirakan dan menunjukkan keuntungan dari spekulasi, bahaya metodis, dan eksekusi perubahan bahaya

5. Perantara untuk kelas sumber daya pada porsi sumber daya.

Daftar yang digunakan dalam tinjauan ini adalah file area moneter, yang berarti bahwa daftar yang melakukan eksekusi nilai semua saham di Papan Utama dan Papan Pengembangan di area Keuangan, mengacu pada Klasifikasi Industri Saham Jakarta (JASICA). Organisasi yang tercatat yang memiliki pendapatan (bagian terbesar) paling banyak yang dihasilkan dari item bisnis/Keuangan dipilih untuk berada di area JASICA Finance. Penawaran baru yang tercatat di Sektor Keuangan JASICA akan diingat untuk file dari tanggal posting. Penawaran yang dihapus dari daftar oleh Sektor Keuangan JASICA akan dihapus dari catatan sejak tanggal penghapusan yang berhasil.

Return

Sebagaimana ditunjukkan oleh Hartono, (2014) dalam (Indriastuti, 2018) return adalah hasil yang diperoleh dari spekulasi. Pengembalian merupakan salah satu inspirasi para financial backer dalam berkontribusi, hal itu juga diimbangi dengan bahaya yang akan didapat oleh financial backer. Pengembalian itu sendiri diisolasi menjadi 2 macam, pengembalian yang diakui secara khusus dan pengembalian yang diharapkan. Pengembalian yang diakui adalah pengembalian yang ada tergantung 
pada estimasi informasi otentik, sedangkan pengembalian yang diharapkan adalah pengembalian yang belum terjadi tetapi dapat diandalkan untuk terjadi di kemudian hari (Nailiu, 2015).

Penyebab pengembalian dari spekulasi terdiri dari 2 bagian prinsip, yaitu imbal hasil spesifik dan penambahan modal/kemalangan. Yield adalah bagian dari return yang mencerminkan pendapatan atau bayaran yang diperoleh dari suatu spekulasi secara berkala. Sedangkan penambahan/penambahan modal adalah penambahan atau pengurangan nilai suatu sekuritas yang dapat berupa angka pendek, nol dan positif (Hutami, 2015).

\section{Beta}

Beta $(\beta)$ adalah proporsi bahaya metodis suatu saham atau portofolio yang dibandingkan dengan bahaya pasar. Beta juga berfungsi sebagai bagian dari ketidakstabilan pengembalian saham, atau portofolio terhadap pengembalian pasar. Ketidakstabilan adalah perubahan kedatangan saham atau portofolio dalam periode tertentu. Apabila perubahan tersebut benar-benar mengikuti kegoyahan return pasar, dikatakan bahwa beta sekuritas bernilai satu (Jogiyanto, 2007).

Keragu-raguan ini menunjukkan bahaya metodis saham, semakin menonjol kedatangan saham berubah dengan pengembalian pasar, semakin penting bahaya efisien, dan sebaliknya, semakin kecil varians keuntungan saham dari pasar. return, semakin sederhana beta dari saham tersebut. karena kebimbangan juga merupakan bagian dari bahaya, beta 1 menunjukkan bahwa bahaya efisien dari suatu sekuritas atau portofolio sama tuanya dengan bahaya. Bahaya signifikan untuk dipertimbangkan dalam bunga sebagai portofolio adalah bahaya metodis, di mana ukuran bahaya ditunjukkan oleh ukuran unit beta.

\section{Abnormal Return}

Abnormal return atau pengembalian tidak biasa adalah perbedaan antara pengembalian nyata dan pengembalian normal. Pengembalian yang tidak biasa secara teratur digunakan untuk survei pameran proteksi (Kusnandar dan Bintari, 2020). Sementara itu, seperti yang ditunjukkan oleh (Hidayah, 2019) imbal hasil yang tidak biasa adalah imbal hasil yang diperoleh penyandang dana yang tidak sesuai dengan asumsi.

\section{Tranding Volume Activity}

Volume pertukaran saham adalah salah satu petunjuk yang digunakan untuk melihat respon pasar terhadap peristiwa atau data yang diidentikkan dengan suatu saham. Perubahan volume bursa diperkirakan dengan pergerakan volume bursa yang diperkirakan oleh Trading Volume Activity (TVA) (Firmansyah dan Agustin, 2016). Sedangkan dari (Widyatmoko et al., 2018)) Pergerakan volume perdagangan adalah jumlah porsi penjamin yang dipertukarkan di pasar modal setiap hari pada tingkat nilai yang disepakati oleh pembeli dan pedagang penawaran melalui bursa efek. spesialis (delegasi).

\section{Kerangka Pikir}

Dilihat dari gambaran premis hipotetik dan penelitian sebelumnya, maka dapat dikatakan bahwa kesempatan peningkatan keuangan publik sebagai strategi countercyclical yang mempengaruhi penyebaran infeksi Covid 2019 setelah ditetapkannya POJK nomor 11 tahun 2020 pada 13 Maret 2020 dan POJK nomor 14 tahun 2020 tanggal 14 April 2020 dapat digunakan sebagai data penelitian berdasarkan studi kesempatan, sebagai kesempatan yang dapat menimbulkan respon pasar modal

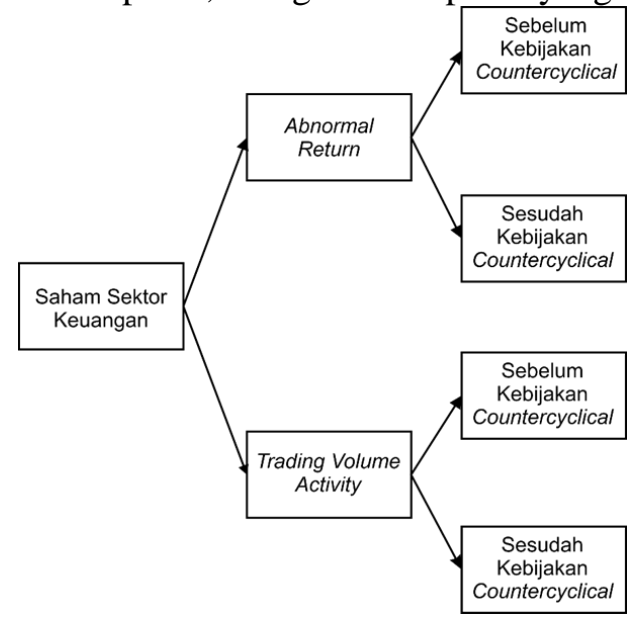

Gambar : 2.1 Kerangka (Sumber: data diolah peneliti (2020)) 


\section{Hipotesis Penelitian}

H1 : Ada perbedaan dalam pengembalian yang tidak biasa sebelumnya, kemudian setelah Kebijakan Kontrasiklus.

H2 : Ada perbedaan dalam Aktivitas Volume Perdagangan sebelumnya, kemudian setelah Kebijakan Countercyclical

\section{METODE PENELITIAN}

Jenis informasi yang digunakan dalam tinjauan ini adalah informasi kuantitatif, sedangkan sumber informasi yang digunakan adalah informasi opsional yang dikumpulkan dari situs otoritas yang diperoleh dari media elektronik. Informasi yang diperlukan dalam tinjauan ini adalah sebagai informasi bursa dan daftar saham organisasi moneter yang tercatat di Bursa Efek Indonesia (BEI) periode 2020.

Review ini mengambil informasi dari Bursa Efek Indonesia (BEI) yang memberikan data ringkasan anggaran organisasi yang bergerak di bidang moneter dengan masuk ke situs otoritas Bursa Efek Indonesia (BEI), tepatnya www.idx.co.id dan www.yahoofinance.com dengan informasi opsional. waktu penelitian dimulai dari Januari 2021 hingga April 2022.

Populasi dalam tinjauan ini adalah seluruh organisasi yang tercatat di area moneter di BEI dari 1 Januari hingga 31 Desember 2020, sebanyak 104 organisasi. Pengujian dalam tinjauan ini dilakukan dengan menggunakan strategi pengujian purposive, yaitu pilihan pengujian yang menggunakan standar tertentu yang ditetapkan oleh ilmuwan tergantung pada perenungan yang tepat dan berkepala dingin. Aturan untuk memutuskan contoh yang digunakan adalah sebagai berikut:

1. Organisasi yang tercatat di area moneter di BEI periode 2020

2. Organisasi yang bervariasi sesuai dengan Indeks Sektor Keuangan (JKFINA).

3. Contoh organisasi tidak melakukan langkah korporasi selama jangka waktu persepsi.

4. memiliki aksesibilitas data atau aksesibilitas informasi yang dimanfaatkan oleh para analis yang terdapat di situs Yahoo Finance.

Teknik pemeriksaan informasi yang digunakan adalah model investigasi uji-t. Di atas segalanya, setelah informasi yang dikumpulkan akan diselidiki secara bertahap melalui pengukuran ilustratif, kemudian, pada saat itu, pengujian faktual dilakukan melalui uji sirkulasi tipikal menggunakan uji Kolmogorov-Smirnov. Selain itu, menguji teori masing-masing variabel eksplorasi menggunakan uji uji Paired Sample T-Test jika informasi yang dikumpulkan diedarkan secara teratur dan model uji investigasi Wilcoxon Signed Rank jika informasinya tidak sesuai.

\section{HASIL DAN PEMBAHASAN Perolehan Sampel Penelitian}

Tabel 4.1 Perolehan Sampel

\begin{tabular}{|l|c|}
\hline Jumlah Perusahaan Sektor Keuangan Periode 2020 & 104 \\
\hline $\begin{array}{l}\text { Perusahaan yang berfluktuatuf tidak searah dengan } \\
\text { indeks sector keuangan }\end{array}$ & -34 \\
\hline Perusahaan yang melakukan Corrporate Action & -5 \\
\hline $\begin{array}{l}\text { Perusahaan yang datanya tidak ditemukan pada yahoo } \\
\text { Finance }\end{array}$ & -14 \\
\hline Total Sampel yang digunakan & $\mathbf{5 1}$ \\
\hline
\end{tabular}

Sumber : Data diolah peneliti (2021)

Berdasarkan tabel di atas, dari 104 organisasi moneter di tahun 2020 terdapat 34 organisasi yang memiliki beta negatif, ada 5 organisasi yang melakukan corporate move selama jangka waktu peninjauan, dan ada 14 organisasi yang informasinya tidak dapat jadi contoh konklusif dari review adalah 51 organisasi. Perhitungan beta dalam ulasan ini menggunakan model file soliter. Perhitungan beta diselesaikan di setiap organisasi area moneter dengan rentang waktu beberapa hari sebelum dan 9 hari setelah acara. Jika organisasi memiliki beta negatif, itu akan dilarang dari uji eksplorasi. 


\section{Statistik Deskriptif}

Tabel 4.2 Statistik Deskriptif

\begin{tabular}{cccccc}
\hline & \multicolumn{5}{c}{ Descriptive Statistics } \\
& $\mathrm{N}$ & Minimum & Maksimum & Mean & Std. Deviation \\
\hline AAR_SEBELUM & 102 & $-0,023986$ & 0,075603 & 0,00654658 & 0,016014809 \\
AAR_SESUDAH & 102 & $-0,051049$ & 0,041589 & 0,00039809 & 0,012618653 \\
ATVA_SEBELUM & 102 & 0,000000 & 2,201996 & 0,14727626 & 0,324258938 \\
ATVA_SESUDAH & 102 & 0,000000 & 2,636781 & 0,16334417 & 0,378052429 \\
Valid $N$ (listwise) & \multicolumn{5}{c}{102} \\
\hline
\end{tabular}

Sumber: data diolah SPSS 26 oleh peneliti (2021)

Abnormal return sebelum kebijakan Countercyclical pada Tabel 4.2 menunjukkan bahwa pada 51 organisasi normal adalah 0,00654658 dengan standar deviasi 0,016014809. Lubang informasi tidak terlalu besar karena simpangan bakunya tidak terlalu jauh dari nol sehingga penyebaran informasi tetap bisa dianggap wajar. Variabel pengembalian tidak biasa sebelumnya memiliki nilai dasar - 0,023986 dan nilai terbesar 0,075603. Pengembalian Aneh setelah Kebijakan Countercyclical pada Tabel 4.2 menunjukkan bahwa pada 51 organisasi normal adalah 0,00039809 dengan standar deviasi 0,012618653 . Lubang informasi tidak terlalu besar karena simpangan bakunya tidak terlalu jauh dari nol sehingga peruntukan informasi tetap bisa dianggap wajar. Variabel pengembalian tidak biasa setelah memiliki nilai dasar - 0,051049 dan nilai paling ekstrim 0,041589.

Volume Pertukaran Aktivitas sebelum Kebijakan Countercyclical Tabel 4.2 menunjukkan bahwa pada 51 organisasi normal adalah 0,14727626 dengan standar deviasi 0,3242589. Lubang informasi tidak terlalu besar karena simpangan bakunya tidak terlalu jauh dari nol sehingga penyebaran informasi tetap bisa dianggap wajar. Variabel aksi volume pertukaran sebelumnya memiliki nilai dasar 0,00000 dan nilai terbesar 2,2011996. Aktivitas Volume Pertukaran setelah Kebijakan Countercyclical Tabel 4.2 menunjukkan bahwa pada 51 organisasi normal adalah 0,16334417 dengan standar deviasi 0,378052429 . Lubang informasi tersebut tidak terlalu besar karena standar deviasinya tidak terlalu jauh dari nol sehingga peredaran informasi tetap bisa dianggap wajar. Setelah variabel pergerakan volume pertukaran memiliki nilai dasar 0,00000 dan nilai tertinggi 2,636781

\section{Uji Normlitas}

Tabel 4.3 Uji Normalitas

\begin{tabular}{lrrr}
\hline & \multicolumn{3}{c}{ Kolmogorov-Smirnov $^{a}$} \\
& Statistic & $d f$ & Sig. \\
\hline AAR_SEBELUM & 0,130 & 102 & 0,000 \\
AAR_SESUDAH & 0,087 & 102 & 0,056 \\
ATVA_SEBELUM & 0,330 & 102 & 0,000 \\
ATVA_SESUDAH & 0,333 & 102 & 0,000 \\
\hline Sumber: data diolah SPSS 26 oleh peneliti
\end{tabular}

Dari hasil tersebut, cenderung terlihat bahwa untuk faktor Abnormal Return dan Trading Volume Activity (TVA) periode sebelum dan sesudah kepastian strategi countercyclical, informasi tidak beredar secara teratur $(\alpha<0,05)$ dengan Kecuali Abnormal Return, maka pada saat itu, uji teori yang digunakan adalah Wilcoxon Signed. Tes Peringkat.

\section{Pengujian Hipotesis Pengujian Hipotesis 1}


Tabel 4.4 Hasil Uji Wilcoxon Signed Rank-Test Abnormal Return

\begin{tabular}{lc}
\hline \multicolumn{2}{c}{ Tes Statistics $^{a}$} \\
\hline AAR_SESUDAH - AAR_SEBELUM \\
Z & $-3,296^{\mathrm{b}}$ \\
Asymp. Sig. (2-tailed) & 0,001 \\
a. Wilcoxon Signed Ranks Test & \\
b. Based On Positive ranks. & \\
\hline
\end{tabular}

Sumber : data diolah SPSS 26 oleh Peneliti (2021)

Hipotesis 1 yang diusulkan dalam tinjauan ini adalah "ada kontras dalam pengembalian yang tidak biasa sebelum dan kemudian strategi countercyclical". Menguji spekulasi berikutnya menggunakan Wilcoxon Signed Ranks Test karena informasi tersebut biasanya tidak disebarluaskan. karena efek samping dari uji keteraturan menunjukkan bahwa informasi tidak tersebar secara teratur. Melalui pengujian ini akan diketahui apakah terdapat perbedaan yang sangat besar antara return aneh sebelumnya, kemudian setelah strategi countercyclical.

Rumusan untuk menguji spekulasi utama adalah:

H0: tidak ada perbedaan dalam pengembalian yang tidak biasa sebelum dan sesudah strategi countercyclical.

Ha: ada kontras dalam pengembalian yang tidak biasa sebelum dan kemudian setelah strategi countercyclical.

Standar tesnya adalah:

H0 diakui apakah kepentingannya $>0,05$

H0 ditolak jika kepentingannya $<0,05$

\section{Pengujian Hipotesis 2}

Tabel 4.5 Hasil Uji Wilcoxon Signed Rank-Test Tranding Volume Activity

\begin{tabular}{lc}
\hline \multicolumn{2}{c}{${\text { Test } \text { Statistics }^{a}}^{c}$} \\
\hline \multicolumn{2}{c}{ ATVA_SESUDAH - ATVA_SEBELUM } \\
$\mathrm{Z}$ & $-0,997^{\mathrm{b}}$ \\
Asymp. Sig (2-tailed) & 0,319 \\
a. Wilcoxon Signed Ranks Test & \\
b. Based On Negative ranks & \\
\hline Sumber : data diolah SPSS 26 oleh peneliti (2021)
\end{tabular}

Hipotesi 2 yang diajukan dalam review ini adalah " ada kontras dalam Aktivitas Volume Perdagangan sebelumnya, kemudian setelah strategi countercyclical". Menguji spekulasi berikutnya menggunakan Wilcoxon Signed Ranks Test karena informasi tidak biasanya disampaikan. karena konsekuensi dari uji kewajaran menunjukkan bahwa informasi tersebut tidak beredar secara teratur. Melalui pengujian ini akan diketahui apakah terdapat perbedaan kritis antara aksi pertukaran volume sebelum dan sesudah strategi countercyclical.

Persamaan untuk menguji spekulasi utama adalah:

H0 : tidak ada perbedaan pergerakan volume pertukaran sebelumnya, kemudian setelah strategi countercyclical.

Ha : ada perbedaan pergerakan volume pertukaran sebelumnya, kemudian setelah strategi countercyclical.

Model tesnya adalah: 
H0 diterima jika signifiakan $>0,05$

H0 ditolak jika signifikan $<0,05$

\section{HASIL DAN PEMBAHASAN}

\section{Perbandingan Abnormal Return (AR) sebelum dan sesudah Kebijakan Countercyclical}

Berdasarkan hasil uji hoptesis yang ditunjukkan, dapat dilihat dengan jelas bahwa ada perbedaan nilai Abnormal Return antara periode sebelum dan kemudian setelah strategi countercyclical. Hal ini menunjukkan bahwa isi data dari peristiwa tersebut cukup mampu membuat pasar modal merespon dan dapat mempengaruhi kecenderungan financial backer dalam menentukan pilihan usaha, sehingga pasar secara keseluruhan mengharapkan data ini, yang tercermin dari perbedaan dalam pengembalian yang tidak biasa. sebelumnya, kemudian setelah pendekatan countercyclical fakta. Hipotesis penandaan menyatakan bahwa ada saat-saat yang dapat menandai respons terhadap data pada pengamatan. Dalam tinjauan ini, para pendukung keuangan berharap bahwa deklarasi pengaturan kontra-siklus adalah data buruk yang tidak dapat meneruskan kemungkinan organisasi besar di kemudian hari. dapat ditunjukkan dengan melihat efek samping dari pengembalian aneh normal yang telah berkurang. Hasil ini mendukung hipotesis efektivitas pasar semi-padat yang mencirikan bahwa nilai saham adalah gambaran dari semua data yang berlaku yang dapat diketahui oleh orang-orang pada umumnya. Konsekuensi dari tinjauan ini sesuai dengan penelitian yang diarahkan oleh (Kusnandar dan Bintari, 2020) (Hidayat, 2018), (Rahmawati dan Pandansari, 2016), dan (Wahyuni dan Widiasmara, 2017) menemukan bahwa terdapat perbedaan abnormal return yang signifikan.

Perbandingan Tranding Volume Activity (TVA) sebelum dan sesudah Kebijakan Countercyclical Berdasarkan Hasil pengujian Hipotesis, tidak ada perbedaan kritis dalam pertukaran tindakan volume manfaat pertukaran pergerakan volume antara periode sebelum dan sesudah strategi countercyclical, ini menunjukkan bahwa tindakan pertukaran oleh para penyokong keuangan di Indonesia antara sebelumnya dan kemudian kemudian strategi countercyclical tidak sepenuhnya berbeda, tidak ada perbedaan besar dalam normal. Aksi volume perdagangan normal sebelumnya, kemudian setelah strategi countercyclical, karena kesempatan strategi countercyclical ini dianggap tidak memiliki data yang signifikan sehingga pendukung keuangan tidak akan merespon. Hal ini menunjukkan bahwa deklarasi strategi countercyclical bukanlah alasan bagi para pendukung keuangan dalam menentukan pilihan keamanan perusahaan. Strategi countercyclical mengarahkan penilaian sumber daya dan membangun kembali kewajiban karena episode Covid-19, sementara para pendukung keuangan menganggap kesempatan Covid-19 ini bersifat sementara, sejujurnya itu benar-benar ada hari ini, sehingga strategi countercyclical tidak akan mempengaruhi situasi ekonomi. Konsekuensi dari tinjauan ini sesuai dengan penelitian (Firmansyah dan Agustin, 2016), (Widyatmoko, Mawardi dan Salim, 2018), (Lestari dan Nuzula, 2018), dan (Romadhona, Maslichah dan Junaidi, 2019) menemukan bahwa volume pertukaran Gerakan tidak menunjukkan perbedaan signifikan pada dasarnya sebelumnya, kemudian setelah kejadian itu.

\section{PENUTUP}

\section{Kesimpulan}

Berdasarkan hasil analisis dan pembahasan yang telah diuraikan sebelumnya, maka penelitian yang bertujuan untuk menganalisis perbedaan abnormal return dan trading volume activity sebelum dan sesudah Kebijakan countercyclical bisa diambil kesimpulan yaitu sebagai berikut:

1. terdapat perbedaan yang signifiakn terhadap abnormal return sebelum dan sesudah strategi kontrasiklus. Hasil review menunjukkan bahwa pasar dapat dikatakan semi solid karena data tentang pengaturan countercyclical merupakan data penting yang dapat diketahui oleh masyarakat secara umum.

2. Tidak ada perbedaanyang signifikan terhadap pertukaran pergerakan volume sebelum dan sesudah strategi countercyclical. tidak ada konten data dalam kesempatan strategi countercyclical sehingga aksi jual beli saham tidak merespon strategi countercyclical.

\section{SARAN}

Berdasarkan hasil dan pemeriksaan yang telah dilakukan oleh peneliti review ini, ternyata masih banyak kekurangan, sehingga masih banyak hal yang perlu diperbaiki dan dipikirkan kembali untuk penelitian selanjutnya. Saran dari penulis untuk pemeriksaan berikut adalah mengumpulkan informasi data saham harian di berbagai situs yang lebih lengkap 


\section{DAFTAR PUSTAKA}

A'immah, S., Suhadak, \& Hidayat, R. R. (2015). Reaksi Abnormal Return Dan Trading Volume Activity Terhadap Ramadhan Effect (Studi Pada Perusahaan Food And Beverages Yang Terdaftar Di Bursa Efek Indonesia Periode 2013-2014). Jurnal Administrasi Bisnis (Jab), 27(1).

Ariani, A. D., Topowijono, \& Sulasmiyati, S. (2016). Analisis Perbedaan Abnormal Return Dan Likuiditas Saham Sebelum Dan Sesudah Right Issue (Studi Pada Perusahaan-Perusahaan Yang Terdaftar Di Bursa Efek Indonesia Tahun 2012-2015). Jurnal Administrasi Bisnis (Jab), 33(2), $49-58$.

Baiquni, R. S. (2015). Pengaruh Pengumuman Hasil Pemilihan Umum Presiden 2014 Terhadap Abnormal Return Dan Aktivitas Volume Perdagangan Saham (Studi Peristiwa Pada Saham Anggota Indeks Kompas100). In Sekolah Tinggi Ilmu Ekonomi (Stie) Muhammadiyah Pekalongan.

Fadel, M. (2019). Analisis Abnormal Return Dan Volatility Return Saham Sebelum Dan Sesudah Fenomena January Effect (Event Study Pada Perusahaan Lq45 Yang Terdaftar Di Bursa Efek Indonesia Tahun 2014-2018). In Jurnal Ilmiah Prodi Manajemen, Fakultas Ekonomi, Universitas Islam Negeri Syarif Hidayatullah (Vol. 53, Issue 9). Universitas Islam Negeri Syarif Hidayatullah Jakarta.

Fadillah, R., Mansur, M., \& Wahono, B. (2020). Perbandingan Abnormal Return Saham Sebelum Dan Sesudah Perubahan Waktu Perdagangan Selama Pandemi Covid-19.

Firmansyah, A. D., \& Agustin, S. (2016). Analisis Perbandingan Trading Volume Activity Dan Abnormal Return Sebelum Sesudah Stock Split. Jurnal Ilmu Dan Riset Manajemen, 5(5), 1-15.

Ghozali, I. (2018). Aplikasi Analisis Multivariat Dengan Program Ibm Spss 25 (9th Ed.). Badan Penerbit Universitas Diponegoro.

Guminto, D. A., \& Marlina, M. A. E. (2019). Dampak Kerusuhan Mako Brimob Mei 2018 Terhadap Abnormal Return Indeks Lq45 Yang Terdaftar Di Bei. Media Akuntansi Dan Perpajakan Indonesia, 1(1), 1-11.

Hanafie, L., \& Diyani, L. A. (2016). Pengaruh Pengumuman Stock Split Terhadap Return Saham , Abnormal Return Dan Trading Volume Activity. Kalbisocio, 3(2), 13-20.

Hasanuddin. (2015). Analisis Komparatif Abnormal Return Saham Jii Dan Non Jii Sebelum Dan Sesudah Libur Idul Fitri (Periode 2009-2013). Jurnal Mix, 6(2), 246-259.

Hidayah, M. K. (2019). Perbedaan Abnormal Return Dan Trading Volume Activity Sebelum, Saat Dan Sesudah Asian Games Jakarta-Palembang 2018 (Studi Kasus Pada Indeks Liquid 45).

Hidayat, R. (2018). Analisis Perbedaan Abnormal Return Sebelum Dan Sesudah Peristiwa Politik Pada Saham Perusahaan Lq-45. Jurnal Ilmu Manajemen, 7.

Hidayati, N., Maslichah, \& Junaidi. (2017). Reaksi Abnormal Return Dan Trading Volume Activity Terhadap Ramadhan Effect. 5(1), 1-8.

Husnan, S. (2001). Manajemen Keuangan Teori Dan Penerapan (Keputusanjangka Panjang). In Edisi Keempat Yogyakarta: Bpfe. Bpfe.

Hutami, R. N. U. R. (2015). Abnormal Return Dan Trading Volume Activity Sebelum Dan Setelah Pemilihan Presiden Secara Langsung 9 Juli 2014 (Studi Kasus Pada Saham Lq-45). Diponegoro Journal Of Accounting, 4(2), 238-247.

Indriastuti, A. (2018). Pengaruh Hari Libur Idul Fitri Terhadap Abnormal Return, Security Return Variability Dan Trading Volume Actvity Pada Jakarta Islamic Index (Jii) Tahun 2013-2016.

Iskamto, D. (2015). Anomaly Pasar Pada Bursa Efek Indonesia. Jurnal Tepak Manajemen Bisnis, 3, 388.

Jogiyanto, H. (2007). Teori Portofolio Dan Analisis Investasi. Bpfe.

Kudus, M. I., \& Sutrisno. (2018). Perbedaan Abnormal Return Dan Trading Volume Activity Atas Peristiwa Peledakan Bom Pada Tiga Gereja Di Surabaya. E-Journal Brawijaya, 1-13.

Kusnandar, D. L., \& Bintari, V. I. (2020). Perbandingan Abnormal Return Saham Sebelum Dan Sesudah Perubahan Waktu Perdagangan Selama Pandemi Covid-19. Jurnal Pasar Modal Dan Bisnis, 2(2), 195-202.

Lestari, D. P. F., \& Nuzula, N. F. (2018). Dampak Britain Exit (Brexit) Terhadap Abnormal Return Dan Trading Volume Activity Pada Indeks Lq-45. Jurnal Administrasi Bisnis (Jab), 55(3), 14-23. 
Liwe, C. T. S., Tommy, P., \& Maramis, J. B. (2018). Reaksi Investor Dalam Pasar Modal Atas Peristiwa Menguatnya Kurs Dolar Amerika Serikat Terhadap Nilai Tukar Rupiah Pada 26 Agustus 2015 (Study Pada Perusahaan Manufaktur Sub Sektor Food And Beverage Yang Listed Di Bei). Jurnal Emba: Jurnal Riset Ekonomi, Manajemen, Bisnis Dan Akuntansi, 6(3), 1058-1067.

Mahaputra, I. M. D., \& Purbawangsa, I. B. A. (2015). Pengaruh Peristiwa Pemilu Legislatif 2014 Terhadap Perolehan Abnormal Return Saham Lq 45 Di Bursa Efek Indonesia. E-Jurnal Manajemen Universitas Udayana, 4(5), 248013.

Mediyawati, A. (2019). Dampak Peristiwa Aksi Bela Islam 2 Desember (Aksi 212) Tahun 2016 Terhadap Abnormal Return Dan Trading Volume Activity. Institut Agama Islam Negeri Kudus.

Nailiu, B. A. (2015). Pengaruh Pengumuman Pencapresan Jokowi 2014 Di Bursa Efek Indonesia (Event Study: "Jokowi Effect" Pada Saham Lq45). E- Journal Universitas Atma Jaya.

Nugroho, V., \& Radyasa, Y. (2019). Pengaruh Likuiditas, Ukuran Perusahaan, Dan Leverage Terhadap Kualitas Laba Pada Perusahaan Manufaktur. 80-91.

Pamungkas, A., Suhadak, \& N.P, M. . W. E. (2015). Pengaruh Pemilu Presiden Indonesia Tahun 2014 Terhadap Abnormal Return Dan Trading Volume Activity ( Studi Pada Perusahaan Pada Perusahaan Yang Tercatat Sebagai Anggota Indeks Kompas100). Jurnal Administrasi Bisnis, 20(1).

Rahmawati, I. Y., \& Pandansari, T. (2016). Reaksi Pasar Modal Dari Dampak Peristiwa Bom Plaza Sarinah Terhadap Abnormal Return Perusahaan Lq 45 Yang Terdaftar Di Bei Ika. Riset Akuntansi Dan Keuangan Indonesia, 1.

Romadhona, J., Maslichah, \& Junaidi. (2019). Pengaruh Peristiwa Bom Bunuh Diri 13 Mei 2018 Di Surabaya Terhadap Abnormal Return Dan Volume Perdagangan Perusahaan Lq45 Yang Terdaftar Di Bei. E-Jra, Vol. 08(03), 1-11.

Utami, A. T. (2017). Analisis Trading Volume Activity Dan Average Abnormal Return Sebelum Dan Sesudah Melakukan Pemecahan Saham (Stock Split) Pada Perusahaan Yang Terdaftar Di Bursa Efek Indonesia. Jurnal Ekonomi Dan Bisnis, 18(2), 164-173.

Utami, T. N., Maski, G., \& Idrus, H. M. S. (2009). Dampak Pengumuman Stock Split Terhadap Return, Variabilitas Tingkat Keuntungan Dan Aktivitas Volume Perdagangan Saham. Wacana, 12(4), 725-739.

Verawaty, Noviardy, A., \& Muhammad, S. (2018). Pengaruh Aksi Damai 212 Terhadap Abnormal Return Saham Pada Kelompok Indeks Saham Lq-45. Jurnal Ilmiah Mbia, 17(3), 13-24.

Wahyuni, R., \& Widiasmara, A. (2017). Dampak Pengumuman Kemenangan Donald Trump Pada Pemilu Presiden Amerika Serikat 2016 Atau "Trump Effect" Terhadap Abnormal Return Saham Lq45 Di Bei. Jurnal Akuntansi, 1(1), 38-44.

Widyatmoko, M. K., Mawardi, R. M., \& Salim, A. (2018). Pengaruh Pengumuman Right Issue Terhadap Abnormal Return Dan Volume Perdagangan Saham. E - Jurnal Riset Manajemen, 4754.

Wulan, D. C., Handayani, S. R., \& Nurlaily, F. (2018). Analisis Abnormal Return Dan Trading Volume Activity Terhadap Pengumuman Unusual Market Activity ( Studi Pada Perusahaan Yang Terdaftar Dalam Pengumuman Unusual Market Activity Di Bei Tahun 2015-2017 ). Jurnal Administrasi Bisnis (Jab), 61(1), 173-180. 